\title{
Research on the Influence Mechanism of Joint Promotion on the Loyalty of the Main Brand
}

\author{
Sartova Zhamilya ${ }^{1}$ \\ ${ }^{1}$ School of Business Administration, South China University of Technology, Guangzhou, China \\ Correspondence: Sartova Zhamilya, School of Business Administration, South China University of Technology, \\ Guangzhou, China. E-mail: jamilu6ka@mail.ru
}

Received: March 27, 2018

doi:10.5539/ijbm.v13n7p222
Accepted: May 12, 2018

Online Published: June 15, 2018

URL: https://doi.org/10.5539/ijbm.v13n7p222

\begin{abstract}
As the economy of commodities continues to grow, people's living standards continue to increase, and the choice of turntables they face is also more abundant. The competition for businesses around the terminal market has become intense and fierce. The number of brands, the fierce market Jinzheng, the increase in similar product readings, and the increase in consumer choices, have also led to the continuous promotion of various promotions by various merchants.

Effective control loyalty management method for a marketing manager is very important, but in the past literature I have not been able to study brand loyalty stand in the perspective of business managers. So to put it plainly that the current research on the support of brand loyalty management methods - the relationship between brand management behavior and brand loyalty - is a blank area, and few scholars have conducted in-depth research. In such a situation, it directly leads the managers of the company to have a full grasp of brand loyalty. In interviews with corporate brand managers, the authors found that brand managers really lack knowledge in this area and urgently need brand loyalty management methods. This article mainly studies the mechanism of the joint marketing promotion on the loyalty of the main brand. First of all, it summarizes the background significance of the research and the research status at home and abroad, and then explains the related theoretical concepts. Then it studies the concept, characteristics, and influencing factors of joint promotion, finally analyzes the ways of building brand loyalty, and proposes related strategies.
\end{abstract}

Keywords: joint promotion, loyalty

\section{Introduction}

As China's market economy gradually matures, corporate competition can no longer rely on products alone, but instead it will gradually rely on brands. Therefore, both academic research and market management are increasingly concerned about the concept of brand loyalty, which plays a significant role in the long-term development of the company. The current trend of economic globalization, resource globalization, and information globalization are obvious. It is very difficult for a product to improve its quality and technology from marketing to marketing (Srini Srinivasan, Rolph Anderson, \& Kishore Ponnavolu, 2002). However, a strong brand can make up for this shortcoming. The difficulties and challenges facing Chinese companies are as follows:

1). Economic globalization and market liberalization have led to the emergence of powerful foreign brands in the Chinese market. The number of these brands has more mature management capabilities, more advanced management thinking and more extensive market experience.

2). Chinese companies have been exploring reform and opening up for nearly 40 years. Some have already gained brand awareness, but they still lack a more advanced brand concept that is more suitable for the modern market. In addition, due to the lack of modern management experience, Chinese companies are also eager to learn from the Western experience of brand development.

3). After the reform and opening up, Chinese consumers became more rational and their products gradually overrun. Changes in consumer attitudes, more and more understanding of the product, more and more focus on brand quality and personalized needs. Many companies still understand marketing as a slogan of temptation and celebrity effect. Under this background of knowledge, their ability to grasp consumers is low. Among them, 
many companies tend to investigate consumer satisfaction, but there are few surveys on consumers and brand loyalty. To be precise, the current managers of Chinese companies are not clear about the relationship between management behavior and brand loyalty. The concepts and theories in this respect are also relatively fragmented.

Contrastive research: Mainly arranges a set of objects or objects of different natures with certain similarities to be compared and compared: through a comprehensive comparison of their differences in construction (causes) and differences in nature (fruits), Find out what the nature (effect) of this object or object is and what causes it.

\section{Related Theory Overview}

\subsection{Joint Promotion Concept}

Co-promotion means that two or more brands or enterprises jointly use one or more promotional methods to promote sales activities based on the sharing of market resources and mutual benefits, so that all parties can compete in a highly competitive market environment. Complementing each other's advantages, adjusting conflicts, reducing consumption, achieving greater promotional effects with less cost, and achieving benefits that are difficult to achieve with individual promotions (Vibhas Madan, \& Rajneesh Suri, 2001).

Each brand has its own specific market and customer base, and has its own channels, marketing models, etc. These are the unique resources of the brand. The joint promotion is in essence the complementarity of market resources between brands. The two exchanged their own apples in their hands. The result was that they were still two apples. Two people had two ideas in their minds. The result of the exchange was two or more thoughts in the minds of the two. The intangible power of the brand is similar to that of people's minds. The result of the joint promotion is $1+1>2$.

\subsection{Basic Concepts and Measurement of Brand Loyalty}

The intrinsic determinants of brand loyalty mainly include the overall research thinking on the intrinsic determinants: through the analysis of behaviors and attitudes, we expect to find certain rules of these behaviors and attitudes, and then use specific cases to confirm or falsify (Jagmohan S. Raju,Sanjay K. Dhar, \& Donald G. Morrison, 1994).

The focus of brand loyalty research on consumer psychology is the relationship between psychological law and brand marketing. There is more attention to brand preference. Research generally believes that there is a high correlation between brand preference and brand loyalty. Therefore, many studies mainly focus on how some variables influence brand preference.

The research on the willingness of buyers for brand loyalty mainly includes the possibility of consumers' intention to purchase products. After consumers generate perceived values, they will further generate purchase intentions, and consumers' purchase intention will usually depend on the benefits obtained by perceptions. value. The consumer behavior is that the consumer is stimulated by the outside world, enters the buyer's consciousness, and then makes purchasing decisions based on the characteristics of the consumer and the decision-making process. The external stimuli that make consumers react include the impact on the choice of products, the choice of brands, the choice of dealers, the timing of purchases, and the quantity of purchases. Therefore, we can see that consumers' behavior will affect their willingness to purchase based on different situations. In the purchase decision-making process, consumers will go through three stages of cognition, emotion, and behavior. Therefore, they will have preferences, beliefs, and perceived quality before the purchase, which can predict the final decision of consumers (Jagmohan S. Raju,Sanjay K. Dhar, \& Donald G. Morrison, 1994).

\subsection{Factors Affecting Brand Loyalty}

It mainly studies the influence of marketing activities on loyalty. Among them, the most research is on advertising and promotion.

The relationship between advertising and brand loyalty: The main research in this area is the influence of advertising on the way and means of dissemination to the public on brand memory, brand awareness, brand selection and brand preference. The conclusion is that advertising can indirectly affect brand loyalty through these aspects. One argument is that advertising has two forms of influence on brand loyalty: one form is to persuade consumers to increase brand loyalty to increase sales, and one is to increase the tendency of consumers to increase sales. According to another view, the advantages of investigating and contrasting advertisements in influencing purchase intentions are not obvious, and the combination of reliability, credibility, information volume and perception does not fully coincide.

The relationship between price-related promotions and brand loyalty: Research in this area must be practical in nature and investigated by tracking actual marketing cases. Most of them are researching the changes in brand 
loyalty of goods in price reductions, promotions, discounts, promotions, and other activities. It is mainly to ascertain whether the price reduction promotion can attract new consumers and whether the price reduction promotion itself will reduce brand loyalty. The conclusion is that although price reduction promotion is a common means of marketing, it does reduce brand loyalty, because it will increase consumers' distrust of the brand's own price and the sensitivity of price reduction promotions.

The influence of public relations on brand loyalty: There are few research results that can be seen in this area. Some scholars have studied the relationship between employee loyalty and consumer loyalty. In summary, it is the loyalty of the employees that can be loyal to employees. Although it is rather obscure, many scholars believe that public relations can indeed improve the brand's reputation and thus influence brand loyalty. Therefore, the relationship between the two should be close.

\section{The Construction of a Theoretical Model}

\subsection{Research Framework}

In the previous section, a comprehensive review of joint marketing, brand awareness, brand reputation, and brand loyalty was conducted. From the previous review of the literature, it can be found that the research theory for single brand promotion is rich and varied, but the research on joint promotion is relatively few. And the literature on the joint promotion of the brand loyalty is very few. However, through observation and sorting, it can be found that joint marketing in the Chinese market has increasingly attracted the attention of companies. Many large companies and brands have already started this new type of promotion and have received good returns (David R. Wheeler, 1974).

\subsection{Research Hypothesis}

This article discusses the effect of joint promotion, brand awareness, and brand reputation on master brand loyalty fruit. Based on the previous literature and discussion, this paper establishes the following assumptions.

\subsubsection{Joint Promotion}

As a new promotion method, joint promotion has gradually been accepted and widely adopted by enterprises. Co-promotion is a high-level form of promotion. It is a transformation and sublimation of a form of promotion. It has a greater impact on target consumers and potential consumers. With the intensification of market competition, the joint promotion has been widely used. Rajah Varadarajan (1985) [651 points out that joint sales promotion has a certain influence on the brand. By joint marketing with different products from another company, both parties can achieve certain market goals. One of them is to increase brand competitiveness.

Peter D Bellllett (1995) and Philip Kotlertl (2000) believe that the tools or methods of promotion are mainly divided into five forms: advertising, sales promotion, public relations, personnel promotion, and direct marketing. Since joint promotion is a category of sales promotion, when examining the joint promotion of brand awareness, brand reputation, and brand loyalty, it should also divide the joint promotion into five dimensions, and then examine their impact on the brand.

Based on this, we put forward the first and second assumptions of this paper. Under each hypothesis, we follow the five dimensions of joint promotion.

Decompose into five small hypotheses:

Hla: Advertising in a joint promotion has a positive impact on brand awareness.

Hlb: Sales promotion in joint promotion has a positive impact on the visibility of the main brand.

Hlc: Public relations in joint promotion have a positive impact on the visibility of the main brand.

Hld: People sales in joint promotions have a positive impact on brand awareness.

Hle: Direct marketing in a joint promotion has a positive impact on brand awareness.

H2a: Advertising in joint promotion has a positive impact on the reputation of the main brand.

$\mathrm{H} 2 \mathrm{~b}$ : Sales promotion in joint promotion has a positive impact on the reputation of the main brand.

$\mathrm{H} 2 \mathrm{c}$ : Public relations in joint marketing have a positive impact on the reputation of the main brand.

H2d: People sales in joint promotion have a positive impact on the reputation of the main brand.

H2e: Direct marketing in joint promotion has a positive impact on the reputation of the main brand.

\subsubsection{Master Brand Awareness}

The reason why consumers choose a brand is because the consumer knows the brand. With the consumers' 
in-depth understanding of the brand, they gradually begin to trust the brand. At this time, the brand brings people beyond the value of the product itself. The purchaser will also think that the product is worth the money or enjoy the value, and in the mind left a good impression on the brand and gradually formed a brand reputation. Sam Walton, the founder of Wal-Mart, famously said: "Please expose your eight teeth to the customer." He also taught: "When customers come to a distance of ten feet from you, you must look at the customer gently. Eyes, encourage him to come to you and ask you for help. "This is the so-called "ten-foot attitude," and Wal-Mart conveys the concept of "providing customers with more valuable and high-quality products," which gives consumers trust and loyalty. And a good brand reputation comes from The word-of-mouth communication between consumers, in order to achieve a higher brand reputation, not only to increase consumer satisfaction, but also to pay attention to the positive information of the dissemination of products, minimize the negative effects, and to take good care of It is difficult to establish licenses and it is difficult to maintain the brand, so the reputation of the brand is vital to the brand's life. To build a strong brand, we must pay attention to the reputation of the brand. Steffen, Georges (126) 1261 points out that brand awareness is the brand reputation. The premise is that there is a strong positive correlation between the two, and if the awareness is low and the reputation is low, the brand is in the market introduction period, and the product (in a broad sense, the service is also the product) quality and brand promotion work We also did not do enough; if the awareness is low and the reputation is high, it means that a good product "is cultivated by someone who is still not known"; if the product's awareness is high, the reputation is low. Easy to give a feeling of notorious; high awareness of high reputation is a very mature product performance, but also easy to form brand loyalty Accordingly, this paper proposes the first three assumptions:

H3: The visibility of the main brand is positively related to the reputation of the main brand.

\subsubsection{Reputation of the Main Brand}

Brand reputation is based on brand awareness. There is no brand awareness, not to mention the formation of a good image of the brand in the minds of consumers. Brand awareness is the basis of reputation; and brand reputation can truly reflect the brand's value in the minds of consumers, both of which are important indicators to measure the degree of brand value. Reputation is a good image of the brand in the minds of consumers. The degree of reputation is premised on the prestige, and there is no good reputation, let alone a good brand image. However, reputation can be rapidly promoted through publicity. The awareness of enterprises and products established through event marketing, soft papers, and various marketing vehicles is not always the same as the brand reputation of an enterprise. Therefore, some CEOs have exclaimed that while product popularity is unprecedented, sales volume of products fluctuates greatly. Only relying on authoritative media advertising and endless promotion campaigns can drive sales. At this time, CEOs realized that brand awareness is only an integral part of brand reputation. Brands with high brand awareness will be more likely to be the object of consideration when purchasing, and thus are more likely to form brand loyalty. Brand reputation refers to every good thing that is connected with the brand in the memory and represents a good image, reputation and reputation. If the brand has a high reputation, that is, it is a very good image in the minds of consumers, and it is a brand with good reputation and good reputation, it is easy to form brand loyalty, and vice versa will lead to a decline in loyalty. For example, the theme of a certain brand is environmental protection, which gives people the impression of caring for the society and caring for human beings. When one day begins to produce cigarettes, it will naturally reduce its image and affect its brand loyalty. It can be seen that brand reputation has a certain influence on brand loyalty. Based on this, the 4th to 6th hypotheses of this paper are proposed:

H4: The reputation of the main brand is positively related to the loyalty of the main brand.

H5: The reputation of the main brand is positively related to the loyalty of the main brand.

H6: The reputation of the main brand is positively related to the emotional loyalty of the main brand.

\section{Hypothesis Verification of SPSS}

\subsection{Data Collection and Descriptive Statistics}

SPSS output results are shown in Table 1 to Table 2. Table 1 shows the frequency of observations for the variables male and female respectively. 
Table 1. Gender frequency

\begin{tabular}{llllll}
\hline & & Use & & & total \\
& & Mild & Moderate & severe & \\
\hline \multirow{2}{*}{ sex } & Man & 10 & 17 & 7 & 34 \\
\multirow{2}{*}{ total } & Women & 10 & 12 & 9 & 31 \\
& & 20 & 29 & 16 & 65 \\
\hline
\end{tabular}

Table 2. Chi-square test

\begin{tabular}{llll}
\hline & price & df & Sig. \\
\hline Pearson & $.976^{\mathrm{a}}$ & 2 & .614 \\
$\mathrm{~N}$ & .979 & 2 & .613 \\
$\mathrm{~N}$ & .091 & 1 & .763 \\
$\mathrm{~N}$ & 65 & & \\
\hline
\end{tabular}

In this case, the $\mathrm{P}$ value of the progressive bilateral test is 0.614 far greater than the significant level of 0.05 , accepting the original assumption that, for this data, the gender and loyalty are independent, and there is no difference between male and female consumers in the use of the data. That is to say, there is no significant difference in the loyalty of male and female consumers.

\subsection{Reliability and Validity Test}

The SPSS output is shown in Table 3 to Table 4, and Table $3 \& 4$ show the actual observed frequency, theoretical frequency and the difference between the values of the gender variable and the consumption variable, respectively.

Table 3. Sex frequency

\begin{tabular}{lrcc}
\hline \multicolumn{4}{c}{ observed expectedresidual } \\
\hline Man $\quad 68$ & 45.0 & 23.0 \\
Women22 & 45.0 & -23.0 \\
Total & 90 & & \\
\hline
\end{tabular}

Table 4. Statistics of sales fees

\begin{tabular}{|c|c|c|c|c|c|c|c|}
\hline & observed & expected & residual & & observed & expected & residual \\
\hline 43 & 1 & 1.8 & -0.8 & 107 & 1 & 1.8 & -0.8 \\
\hline 46 & 1 & 1.8 & -0.8 & 108 & 1 & 1.8 & -0.8 \\
\hline 50 & 1 & 1.8 & -0.8 & 109 & 1 & 1.8 & -0.8 \\
\hline 56 & 2 & 1.8 & 0.2 & 110 & 1 & 1.8 & -0.8 \\
\hline 58 & 1 & 1.8 & -0.8 & 112 & 2 & 1.8 & 0.2 \\
\hline 60 & 1 & 1.8 & -0.8 & 115 & 1 & 1.8 & -0.8 \\
\hline 63 & 3 & 1.8 & 1.2 & 117 & 1 & 1.8 & -0.8 \\
\hline 65 & 1 & 1.8 & -0.8 & 119 & 1 & 1.8 & -0.8 \\
\hline 66 & 4 & 1.8 & 2.2 & 124 & 1 & 1.8 & -0.8 \\
\hline 68 & 2 & 1.8 & 0.2 & 126 & 2 & 1.8 & 0.2 \\
\hline 70 & 2 & 1.8 & 0.2 & 133 & 1 & 1.8 & -0.8 \\
\hline 73 & 1 & 1.8 & -0.8 & 140 & 2 & 1.8 & 0.2 \\
\hline 75 & 1 & 1.8 & -0.8 & 142 & 2 & 1.8 & 0.2 \\
\hline 77 & 3 & 1.8 & 1.2 & 143 & 1 & 1.8 & -0.8 \\
\hline 79 & 1 & 1.8 & -0.8 & 153 & 2 & 1.8 & 0.2 \\
\hline 81 & 1 & 1.8 & -0.8 & 161 & 1 & 1.8 & -0.8 \\
\hline 84 & 2 & 1.8 & 0.2 & 164 & 1 & 1.8 & -0.8 \\
\hline 86 & 3 & 1.8 & 1.2 & 165 & 1 & 1.8 & -0.8 \\
\hline 87 & 1 & 1.8 & -0.8 & 170 & 1 & 1.8 & -0.8 \\
\hline 89 & 1 & 1.8 & -0.8 & 177 & 1 & 1.8 & -0.8 \\
\hline 91 & 2 & 1.8 & 0.2 & 178 & 1 & 1.8 & -0.8 \\
\hline 94 & 1 & 1.8 & -0.8 & 181 & 1 & 1.8 & -0.8 \\
\hline 96 & 1 & 1.8 & -0.8 & 191 & 1 & 1.8 & -0.8 \\
\hline 98 & 2 & 1.8 & 0.2 & 200 & 20 & 1.8 & 18.2 \\
\hline 101 & 1 & 1.8 & -0.8 & Total & 90 & & \\
\hline 105 & 2 & 1.8 & 0.2 & & & & \\
\hline
\end{tabular}




\subsection{Regression Analysis of Loyalty}

After completing the correlation analysis of the data, the loyalty is regarded as the explained variable, and the dependent variable is used as the explanatory variable. The results are as follows:

Table 5. Variable table

\begin{tabular}{llll}
\hline \multicolumn{2}{l}{ Input / removed variable $^{\mathbf{b}}$} & & \\
\hline model & entered variable & Removed variable & method \\
\hline 1 & $\mathrm{X} 13^{\mathrm{a}}$ & $\cdot$ & import \\
\hline
\end{tabular}

a. Variables that have entered all requests.

b. dependent variable : X11_12.

Table 6. Variance analysis table

\begin{tabular}{cllllll}
\hline $\begin{array}{c}\text { Anova }^{\mathbf{b}} \\
\text { model }\end{array}$ & & quadratic sum & df & mean square & F & Sig. \\
\hline 1 & recurrence & 31.892 & 1 & 31.892 & 96.978 & $.000^{\mathrm{a}}$ \\
& residual & 38.806 & 118 & .329 & & \\
& amount & 70.698 & 119 & & & \\
\hline
\end{tabular}

a. Predictive variable: (constant), X1_3.

b. dependent variable : X11_12.

F statistic value is $96.978 \% \mathrm{P}=0.000<0.01$.

It shows that the effect of overall regression analysis on model is significant and effective.

The significant test value of parameter $\beta_{-} 0$ was 2.456 .

The $\mathrm{P}$ value is $0.015>0.01$ after retaining three decimal places, which indicates that there is no significant correlation between the two variables.

The dependent variable can not be used to explain the status quo of loyalty when the significant level is 0.01 , so the better the dependent variable is, the higher the probability of success is.

4.4 Regression Analysis of Loyalty

Using loyalty as the explanatory variable and loyalty as the explanatory variable, the regression analysis is carried out. The results are as follows.

Table 7. Analysis of variance table

\begin{tabular}{|c|c|c|c|c|c|c|}
\hline \multicolumn{7}{|c|}{ Anova $^{b}$} \\
\hline & & quadratic sum & $\mathrm{df}$ & mean-square value & $\mathrm{F}$ & Sig. \\
\hline \multirow[t]{3}{*}{1} & recurrence & 28.578 & 1 & 28.578 & 80.060 & $.000^{\mathrm{a}}$ \\
\hline & residual & 42.120 & 118 & .357 & & \\
\hline & amount & 70.698 & 119 & & & \\
\hline
\end{tabular}

a. Predictive variable: (constant), X4_8.

b. dependent variable : X11_12.

The statistical value of $\mathrm{F}$ is $80.060 \% \mathrm{P}=0.000<0.01$.

It shows that the effect of overall regression analysis on model is significantly related. 
Table 8. Coefficient table

\begin{tabular}{|c|c|c|c|c|c|c|}
\hline \multicolumn{7}{|c|}{ Coefficient $^{a}$} \\
\hline \multirow[b]{2}{*}{ model } & & \multicolumn{2}{|c|}{ Non-standardized coefficient } & \multicolumn{3}{|c|}{ Standard coefficient } \\
\hline & & B & standard error & trial version & $\mathrm{t}$ & Sig. \\
\hline 1 & (constant) & .767 & .258 & & 2.977 & .004 \\
\hline & $\mathrm{X} 48$ & .739 & .083 & .636 & 8.948 & .000 \\
\hline
\end{tabular}

a. dependent variable: X11_12

A significant test was performed on parameter $\beta 0$ to obtain a $t$ - test value of 2.97 .

$P$ value was $0.004<0.01$ when three decimal places were retained.

This shows that loyalty can be used to explain current developments. And because of the positive correlation between the two, that is, the better the loyalty, the higher the loyalty.

Standard regression equation: $\mathrm{X} 11$ ?

\section{Regression Analysis between Subjective Norms and Loyalty}

Using loyalty as explained variable and subjective norm as explanatory variable, regression analysis is carried out. The results are as follows

All variables enter regression model

Table 9. Analysis of variance table

\begin{tabular}{cllllll}
\hline $\begin{array}{c}\text { Anova }^{\text {b }} \\
\text { model }\end{array}$ & & & & & & \\
quadratic sum & df & mean-square value & F & Sig. \\
\hline \multirow{2}{*}{1} & recurrence & 16.145 & 1 & 16.145 & 34.923 & $.000^{\mathrm{a}}$ \\
& residual & 54.553 & 118 & .462 & & \\
& amount & 70.698 & 119 & & & \\
\hline
\end{tabular}

Notes. a. Predictive variable: (constant), X9_10.

b. dependent variable : X11_12.

$\mathrm{F}$ was 34.923.

$P$ value is $0.000<0.01$.

It shows that the effect of overall regression analysis on model is significantly related.

The value of $t$ test is 6.827

$P$ value was 0.000 when three decimal places were retained.

Subjective norms can be used to explain the impact of financial risk on loyalty. And the positive correlation between the two, so the better the subjective norms of loyalty, the higher the success rate of loyalty.

The standard regression equation: $X_{-}$(11) $\mathrm{S}_{-}$(12) $1.6450 .392 \mathrm{X}_{-} 9 \backslash+_{-}{ }_{-}$?

\subsection{Hypothesis Testing and Result Analysis}

Based on the second and third chapters, the research model of this paper is established. Determined by joint promotion is an independent variable: brand awareness, brand reputation as the intermediate variable; brand loyalty as the dependent variable research framework, and establish the research hypothesis of this article. The research hypotheses in this chapter are summarized and analyzed as follows:

Hla: Advertising in a joint promotion has a positive impact on brand awareness.

Hlb: Sales promotion in joint promotion has a positive impact on the visibility of the main brand.

Hlc: Public relations in joint promotion have a positive impact on the visibility of the main brand.

Hid: People sales in joint promotions have a positive impact on the visibility of the main brand.

Hle: Direct marketing in a joint promotion has a positive impact on brand awareness.

H2a: Advertising in joint promotion has a positive impact on the reputation of the main brand.

$\mathrm{H} 2 \mathrm{~b}$ : Sales promotion in joint promotion has a positive impact on the reputation of the main brand. 
H2c: Public relations in joint marketing have a positive impact on the reputation of the main brand.

$\mathrm{H} 2 \mathrm{~d}$ : People sales in joint promotion have a positive impact on the reputation of the main brand.

Direct marketing in $\mathrm{H} 2 \mathrm{e}$-joint promotion has a positive impact on the reputation of the main brand.

H3: The visibility of the main brand is positively related to the reputation of the main brand.

H4: The reputation of the main brand is positively related to the loyalty of the main brand.

H5: The reputation of the main brand is positively related to the loyalty of the main brand.

H6: The reputation of the main brand is positively related to the emotional loyalty of the main brand.

\section{Conclusion}

Customer loyalty is an important reflection of enterprise brand, which is of great significance to enterprises. Chi-square testing of market survey data through SPSS software can help marketers make correct marketing decisions and understand customer loyalty. To meet the needs and expectations of customers, effectively eliminate and prevent customer complaints and complaints, continuously improve customer satisfaction, promote customer loyalty, and build a mutual trust between enterprises and customers. Interdependent "quality value chain".

\section{References}

Choong, L. H. (1998). The theory of reasoned action applied to brand loyalty. Journal of Product \& Brand Management. https://doi.org/10.3969/j.issn.1006-480X.2002.08.011

David, R. (1974). Wheeler Brand loyalties: qualitative, quantitative, or both? Journal of the Academy of Marketing Science, (4). https://doi.org/10.3969/j.issn.1005-0892.2003.06.014

Jagmohan, S. R., Sanjay, K. D., \& Donald, G. M. (1994). The Effect of Package Coupons on Brand Choice. Marketing Science, (2). https://doi.org/10.3969/j.issn.1004-4892.2006.03.017

Srini, S. Srinivasan, R. A., \& Kishore, P. (2002). Customer loyalty in e-commerce: An exploration of its antecedents and consequences. Journal of Retailing, 1. https://doi.org/10.3969/j.issn.1000-2154.2005.04.013

Vibhas, M., \& Rajneesh, S. (2001). Quality perception and monetary sacrifice: A comparative analysis of discount and fixed prices. Journal of Product \& Brand Management, (3). https://doi.org/10.3969/j.issn.1004-6917.2004.09.016

\section{Copyrights}

Copyright for this article is retained by the author(s), with first publication rights granted to the journal.

This is an open-access article distributed under the terms and conditions of the Creative Commons Attribution license (http://creativecommons.org/licenses/by/4.0/). 